\title{
Nonverbal components of the populist style of political communication: A study on televised presidential debates in Poland
}

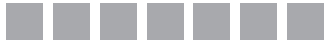 \\ Dorota Piontek \\ ORCID: 0000-0002-6315-7609 \\ ADAM MICKIEWICZ UNIVERSITY, POZNAŃ, POLAND \\ Małgorzata Tadeusz-Ciesielczyk \\ ORCID: 0000-0001-8488-578X \\ AdAM MICKIEWICZ UNIVERSITY, POZNAŃ, POLAND
}

DOI: 10.19195/1899-5101.12.2(23).3

\begin{abstract}
While much of the scholarship on populist political communication focuses on its content and a verbal style, less is known about the nonverbal cues accompanying populist messages. This paper aims in filling that gap by providing findings of the study on characteristics of nonverbal communication of two Polish presidential candidates: Bronisław Komorowski and Andrzej Duda, traced during two debates broadcast on television before the second round of the presidential elections in 2015. The results revealed that both candidates employed nonverbal cues such as appearance, eye contact, facial expressions, or gestures that emphasized their references towards the people or negative attitudes towards elites expressed in their verbal messages. The study also proved that the methods used previously in research on nonverbal content on television (observational protocols and analysis of facial expressions) may be successfully employed in studies on nonverbal components of the populist style of communication.
\end{abstract}

KEYWORDS: nonverbal communication, populism, political communication, television debates, elections.

\section{INTRODUCTION: POPULISM AS A POLITICAL STYLE}

In the literature, several main approaches to populism can be found. These categorize populism as a (thin) ideology (Mudde, 2004), as a strategy for mobilizing voters outside of institutions (Jansen, 2011), as a discourse, and as a political logic (Laclau, 2005). While many scholars define populism as a thin ideology, a large part of its 
appeal is stylistic. Therefore, some other scholars (Jagers \& Walgrave, 2007; Moffitt \& Tormey, 2014; Moffitt, 2016; Kriesi, 2014) propose that populism is a political style that can be defined as "the repertoires of embodied, symbolically mediated performance made to audiences that are used to navigate the fields of power that comprise the political, stretching from the domain of government through to everyday life" (Moffitt, 2016, p. 38). Populist communication can be broken down into two dimensions. The first dimension relates to what is being said. Most of the scholars trace the main elements of populist (thin) ideology, such as approaching the public, anti-elitism, and exclusion of others in the content of the political actors' messages (Mudde, 2004; Jagers \& Walgrave, 2007; Albertazzi \& McDonnell, 2008; Kriesi, 2014). Moffitt (2016, p. 45) adds one more feature of that style, that is the advancing of a narrative of crisis, breakdown or threat. The second dimension relates to how it is being said and focuses on the stylistic or rhetorical features being used for that, such as a colloquial, emotional, dramatizing language, a rejection of the conventions of political or even polite discourse (harshness in attacking opponents), and simplicity and directness (Moffitt, 2016; Reinemann et al., 2017; Bracialle \& Martella, 2017).

The ideological viewpoints of populist politicians often "provide the starting point and lay the groundwork for the communicative acts in which populist elements can be empirically detected" (Reinemann et al., 2017, pp. 13-14). In line with this argument, it is argued that politicians who share a populist ideology can also be distinguished from mainstream politicians by their verbal communication style (ibidem). On the other hand, a populist style is a gradational phenomenon a populist leader or a populist party can become more or less populist across time and space (Moffitt, 2016). Moreover, mainstream actors, as well as journalists and citizens, can adopt a populist style (Reinemann et al., 2017).

Moffitt (2016) describes a populist style as a "sort of cousin to discourse theory," but his scheme includes both verbal and nonverbal forms of communication within the meaning of performance, while discourse analysis focuses on text (Moffitt, 2016, pp. 39-40). Although one may argue with such a contention that "political style" is distinct from discourse (Margulies, 2017), Moffitt (2016) is right to point out the limitations of studies that only focus on texts as measures of populism. Still, little is known about the nonverbal components of the populist style of political communication that is, the use of nonverbal cues either accompanying or replacing verbal messages.

In this paper we aim to contribute to this gap in the literature and focus on characteristics of particular nonverbal cues of political actors. With this study we propose a design of the examination of nonverbal components of the populist style of political communication as well as recognizing the potential and limitations of such research. In particular, we study nonverbal communication of two Polish presidential candidates: Bronisław Komorowski and Andrzej Duda, during two debates broadcast on television before the second round of the presidential elections in 2015. The main focus of the study is on the use of nonverbal communication by these two candidates while speaking about or to the public, elites, and others. 
We argue that a televised presidential debate provides a unique opportunity for using a populist style of communication (both in a verbal and nonverbal dimension) by political rivals due to three main reasons: (1) the character of presidential elections (general elections where candidates want to reach a wide range of voters and thus often employ populist strategies in their statements), (2) timing (the last few weeks prior to election day when competition becomes fierce and candidates want to attract support from as many voters as possible), and (3) the unique characteristics of television that allow politicians to reach a mass audience with their message.

In the paper, we first provide the general characteristics of populist political communication. This is followed by a presentation of the theoretical background to explain how nonverbal cues may be related to verbal messages in case of the populist style of political communication. Then, we will provide characteristics of a televised presidential debate in the context of populist political communication. The subsequent sections of the paper contain a presentation of the study design and the findings from an analysis of several nonverbal cues of two Polish presidential candidates in 2015. We conclude this paper with a discussion of the results and recommendations for future research.

\section{NONVERBAL COMPONENTS OF A POPULIST COMMUNICATION STYLE}

While verbal communication is supposed to be a transmitter of solid evidence, nonverbal communication on the other hand is supposed to implicate what the speaker truly means, enriching their message with mimics, gesticulation, and mood (Bierach, 2001). Furthermore, nonverbal communication always creates the context for what is being said - whether it supports, negates, or replaces it as a sole message carrier.

Bucy (2018) claims that although we prioritize language in politics, we are constantly processing information via other sensory indicators, especially vision. In particular, we form judgments about a person based on their expressions, gestures, and other nonverbal indicators such as posture and tone of voice that are often distinct from those we form based on their words or actions (see also: Aronson, Wilson, \& Akert, 1997). Therefore, Bucy (2018), who investigates the types and effects of televised leader displays on voters, argues that political visuals can serve as reliable sources of social information for two reasons: (1) because they are easy to process and (2) because they require minimal literacy (see: Fowler, 2018). Bucy (2018) believes that visuals are the "equalizing agent of communication" and they are able to level some knowledge gaps we see in the electorate and resonate with a wider constituency because nonverbal communication typically conveys emotion and motivational intent far more accurately than verbal communication (Fowler, 2018).

Although this study does not follow Bucy's examination of cognitive, emotional, and psychological consequences of nonverbal components of leader portrayals on television news (Gong \& Bucy, 2016), we employ his perspective focused on nonverbal components and his approach to populism: According to Bucy (2018), 
populism "can be understood not only from a policy standpoint but also as a nonverbal phenomenon." In nonverbal components a populist style of communication translates into a combination of simplification (obvious displays that are easy to understand), emotionalizations (conveyed through gestures, abrasive tone of voice, or interrupting others' speech), and negativity (the implied disruption or even violence present in the nonverbal cues) (Fowler, 2018).

In order to study nonverbal cues accompanying populist verbal messages we should first emphasize that neither nonverbal cues of communication themselves, nor particular behavior is per se populist. This argument goes alongside previous observations about the features of a populist communication style such as emotionalization, dramatization, negativity, privatization, simplification and generalization, and approaching people (Reinemann et al., 2017), as well as metaphors, overstatements, and direct, rude, simplified, emotional language (e.g., Hameleers, Bos, \& de Vreese, 2017). Although empirical research has indeed shown that the communication style of populist politicians differs from the communication style of politicians from mainstream or traditional parties (e.g., Bracciale \& Martella, 2017), the simple occurrence of the above-mentioned features of communication is not enough to define a political actor as a populist.

However, we may argue that some nonverbal communication cues may play a significant role in populist political communication due to their potential role in expressing emotions, attitudes, and relations. Hence, nonverbal communication can be treated as a manifestation of a populist style of political communication, which aims at arousing emotion from its viewers (the people), creating an image of a given politician as someone who is in touch with the people and their issues, someone who can be their one and only representative. Furthermore, nonverbal communication may be used to emphasize a negative attitude towards elites or some categories of "others" that should be excluded from the public.

Since this is a pilot study, we decided to take into consideration all the main cues of nonverbal communication, that is, the individual speaker's appearance, kinesics (gestures, facial expressions, body posture, and the way of moving), touch, and proxemics. By studying all the main channels of nonverbal communication - one by one - we would be able to examine their potential to express a political actor's attitudes towards the public, elites, and others.

First of all, research indicates that associating someone with features such as integrity, intelligence, trust, skills, confidence, strength, happiness, and success are equal to perceiving them as attractive and physically fit (Sikorski, 2011). This is not limited to physical elements such as height, build or muscle mass, but also includes how one is dressed, hairstyle, and accessories. The way one dresses can not only improve one's physical appearance but also influence how a person is perceived by others.

Previous studies showed that populist political actors' dress code enhanced their public images as nonconformist rebels who break established rules. For example, a study on J. Haider (a long-time leader of Austrian Freedom Party) showed that while 
most male politicians would wear suits and ties, Haider would appear in blue jeans, $\mathrm{t}$-shirt, and jacket since that image is particularly appealing to potential protest voters who are disenchanted with their established voting preferences and traditional party loyalties. Furthermore, he always adjusted his appearance to the group of people he was about to meet: country people, young people, or business people (Wodak \& Pelinka, 2002). In the Polish context two political actors used a similar strategy: Andrzej Lepper (the late leader of Samoobrona in the early years of his political career) and Paweł Kukiz (leader of Kukiz'15, a rock star and political activist).

Facial expressions should be considered as a second important part of nonverbal communication, since the human face is the single most important source of emotional feedback (Leathers, 2007). Communication through facial expressions allows for enrichment of spoken words and expressing emotions accompanying them. Mimics serve not only as a form of emotional feedback, but also a manifestation of one's attitude towards others through facial "comments" during conversations (Sikorski, 2011). As such, mimics may express the political actor's emotions and attitudes towards either people (positive), or elites and others (negative).

The third element is kinesics, which deals with the communicational dimension of movement, especially body positioning, posture, gestures, and other types of physical presentation used as a form of communication. It can indicate shyness or confidence, relaxation or anxiety, as well as the attitude towards some particular groups of people or topics being discussed (Sikorski, 2011). Similar to facial expression, kinesics may strengthen verbal references to the public, elites, or others.

Touch and space are crucial elements in broadcasting a message in relations between participants of the communication process. A welcoming handshake is very popular in the political world, but the strength behind the handshake needs to be well-balanced in order to avoid the "weakling" or "bone-breaker" effects. Time spent on the handshake is also important, as is maintaining eye contact during the handshake. It is seen unfavorably if someone uses the left hand to cover the handshake: it may be received as a way of securing superiority, which can be indicative of low self-esteem and lack of confidence in their own power at the same time. On the other hand, trespassing into someone's space may be perceived as dominating and even aggressive behavior (Sikorski, 2011).

\section{PRESIDENTIAL DEBATES ON TELEVISION AS A CONTEXT OF POPULIST COMMUNICATION}

Televised debates are a very important form of political communication for several reasons. First of all, their structure is determined through extensive negotiations between the candidates' campaigners. In most cases, the order of presentation and duration of speech of each candidate, rules of responding to each other's statements and the main topics, are agreed upon by the host and the political actors. What remains outside the candidates' control is the behavior of their opponents and specific questions asked by the journalists hosting the debate. In such cases candidates need 
to react on the spot and improvise (Schrott, 1990). Since much of the message presented by a candidate may be planned and presented with only limited interruption, the content and style of political communication during the debate may be seen as a manifestation of the electoral strategy (McKinney \& Carlin, 2004).

Secondly, televised debates provide access to far wider audiences than any other form of political communication (such as political advertising or even posters) due to the mass audience of television. In Poland, television is still the main source of information about political issues for as many as 79 percent of Polish potential voters (CBOS, 2015). Thirdly, debates broadcast live on television allow for a wider presentation of political views and ideas, as they run for longer than e.g., television commercials. Finally, debates tend to generate huge media attention, which in turn can result in media exposition in the form of journalists' and experts' comments, analyses, and reports (Hart \& Jarvis, 1997; Choi \& Benoit, 2013).

It needs to be noted, however, that since the emergence of televised debates the validity of the term "debate" has been questioned. Auer (1962), for example, outlined five features of a perfect debate, stemming from American educational, judicial, and parliamentary tradition: a confrontation; an equal and adequate time; comparable participants; a consistent assumption and reaching a decision. While analyzing the Nixon vs. Kennedy debate in 1960, Auer (1962) compared it to a bilateral press conference and declared it as a "counterfeit debate," which pertained more to image than issues. He claims that "the broadcasts emphasized personalities rather than issues, and this may have been intentional. But debates in the American tradition have been clashes of ideas, assumptions, evidence, and arguments, not images" (Auer, 1962, p. 148). Nimmo (2001, p. 184) agrees that the name "debate" is a mismatch for the described format and suggests "confrontation of images" as a better descriptor, while Hellweg, Pfaw, \& Brydon (1992, p. 73) claim that "the visual component of television communication dwarfs the verbal dimension."

The study emphasizes the role of television as a setting (venue) of debate, as well as a channel of political communication which - due to its visual nature - helps to create vivid images in the minds of recipients which leads to their emotional involvement in the debate. It goes alongside Moffitt's (2016, pp. 74-76) claims that a populist style is a mediated one, that is, populists depend on various forms of mass media to circulate their messages (both verbal and nonverbal), and media culture in turn provides the format, language, symbols and arenas for their dissemination.

\section{THE STUDY}

The aim of the analysis was to define nonverbal communication cues employed by two Polish presidential candidates in the 2015 election, supported by two oppositional political parties: the incumbent Bronisław Komorowski, supported by Platforma Obywatelska (Civic Platform) and Andrzej Duda, supported by Prawo i Sprawiedliwość (Law and Justice). For the purposes of this study we use a communication approach to 
populism that "takes a starting point in key characteristics of populist communication and then analyzes the extent to which different actors make use of these, without an a priori classification of who is a populist or not" (de Vreese et al., 2018).

In particular, the goal of the study is to recognize similarities and differences in the candidates' nonverbal behaviors (RQ1), and the populist style that would be manifested by appealing to emotions (positive towards the public and negative towards elites), creating bonds with the viewers (the public) by nonverbal communication, or expressing a negative attitude towards those who are criticized and detached from the public (elites and others) (RQ2).

Methodology employed in the study ranged from observation (Altmann \& Sundstrom, 1974), as a starting point for a collection of core material, to "nonverbal content analysis" (Friedman, Di Matteo, \& Mertz, 1980) of the communication behaviors such as: appearance, posture, gestures, touch, and proxemics (Keltner et al., 2003; Ekman, 1982, 2001). Finally, we examined facial expressions with the use of the Facial Action Coding System (FACS).

The FACS systematizes human face movements based on the method developed by Ekman and Friesen (published in 1978 and updated in a significant way in 2002). Movements performed with individual facial muscles are coded via FACS based on minimal, immediate facial changes (Hamm et al., 2011). In order to minimize subjectivity in the study, FACS has been prepared as an automated program through which it is possible to detect and analyze faces present in pictures, in films or other recordings. The program brings out the geometric features of the face and then creates temporal profiles of each face movement (Hamm et al., 2011).

It is worth emphasizing that the system makes it possible to encode any natural, anatomically possible facial expression that can be obtained by the autonomous facial muscle system, even ambiguous and subtle sensations. It was achieved by a deconstruction of each anatomically possible facial expression into a single action unit, that is a contraction or relaxation of at least one muscle. There are several categories of action units, including: main action units, head movement action units, or eye movement action units. The FACS manual contains over 500 pages along with action units and an interpretation of their meaning proposed by Ekman and Friesen (1978).

In the past, researchers have been manually coding video recordings of participants according to the action units described by the FACS. This process is now possible to complete with automatic facial expression analysis that aims to classify and name the movements on the human face. For the purpose of this study we used the automatic facial expression analysis tool.

In order to provide answers to the research questions, firstly, muted video was analyzed, and later on, the same material was examined with the sound turned on. Consequently, at the first stage the actual content of speech and knowledge behind it were dismissed, while at the second stage a combined verbal and nonverbal message was assessed. The findings from the study will allow us to discuss not only the 
similarities and differences in nonverbal cues used by both candidates, but also the potential and limitations of the design of our study to examine nonverbal behavior of political actors in general, and nonverbal cues accompanying populist messages, in particular.

The subject of the analysis was the content of two presidential debates preceding the second round of the 2015 Polish presidential ballot. The first one took place on May 17, 2015 and was organized by two television broadcasters: TVP SA (public) and Polsat (commercial). The second one was organized by the other commercial television station - TVN on May 22, 2015. Both debates were recorded and stored with the Content Analysis System for Television (CAST). ${ }^{1}$

\section{NONVERBAL COMMUNICATION OF KOMOROWSKI AND DUDA}

\section{Physical appearance}

Komorowski (Picture 1) chose a black suit. Black symbolizes authority, strength, longevity and durability, intelligence, elegance, but also evil (Łoszewski, 2014). A white shirt was chosen to accompany the suit, signifying innocence and security (as white is the most neutral of all colors). Contrasting black and white is rarely seen in the business and political world, and is viewed as the highest form of elegance. The outfit was completed by a navy blue tie symbolizing neutrality (during the debate brodcast by TVP), and a red one during the debate broadcast by TVN. He also wore frameless glasses.

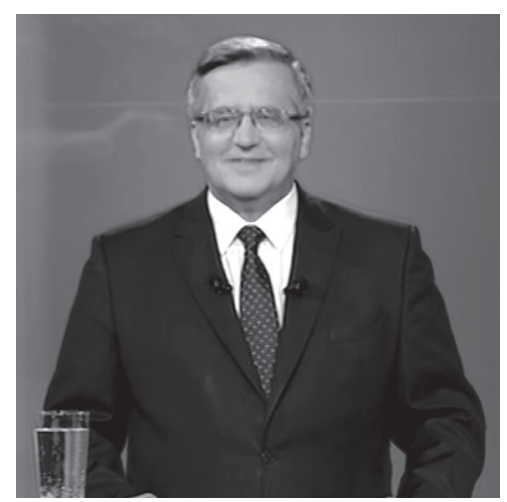

Picture 1. Komorowski's physical appearance

Source: TVP Info. Retrieved August 20, 2016, from http://www. tvp.info/20097155/80-minut-starcia-na-wyborczym-ringu-zobaczcala-debate-komorowskiduda.

Duda (Picture 2) was dressed in a navy blue suit (a safe, neutral color in a business setting, can give off an impression that the dresser will not back down in negotiations), white shirt with cufflinks, and a dark blue (TVP) or red (TVN) tie. Duda also wore jewelry — his wedding band, cufflinks, and a Polish flag pin.

1 The system was developed at the Faculty of Political Science and Journalism at Adam Mickiewicz University in Poznań, Poland. 


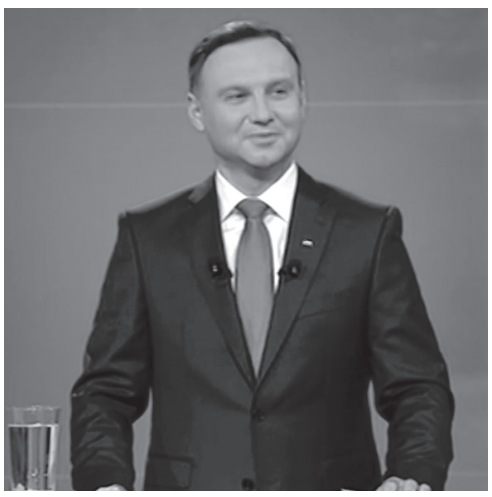

Picture 2. Duda's physical appearance

Source: TVP Info. Retrieved August 20, 2016, from http:// www.tvp.info/20097155/80-minut-starcia-na-wyborczym-ringuzobacz-cala-debate-komorowskiduda.

It is worth noting that both candidates chose dark blue ties for the first debate. The second debate, closer to the election Sunday, was far more pronounced in symbols relating to authority and power, which could be embodied by the red ties.

\section{Facial expression}

Komorowski often smiled whilst providing answers, but his smile was quite often fake and studied (Picture 3), which can be seen by disengaged muscles around the eye sockets and the lack of the "laughing face" effect. A true smile is characterized by maintaining facial symmetry and activates eyes and the surrounding muscles (Ekman, 2003). Komorowski's nervous blinking during his statements was also noticeable. Borg (2011) notes that a person blinks 8 to 15 times a minute on average in order to maintain moisture in the eye, while people under pressure or stress can blink up to 40 times a minute. Other elements of facial expression noted was Komorowski's raised eyebrows (Picture 4) that could indicate surprise or doubt, while clenched teeth and wide nostrils could indicate disapproval, anger, or contempt (Picture 5).

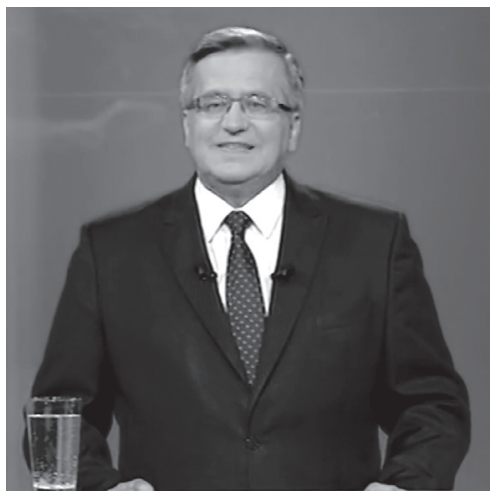

Picture 3. Komorowski's "practiced smile"

Source: TVP Info. Retrieved August 20, 2016, from http:// www.tvp.info/20097155/80-minut-starcia-na-wyborczym-ringuzobacz-cala-debate-komorowskiduda. 

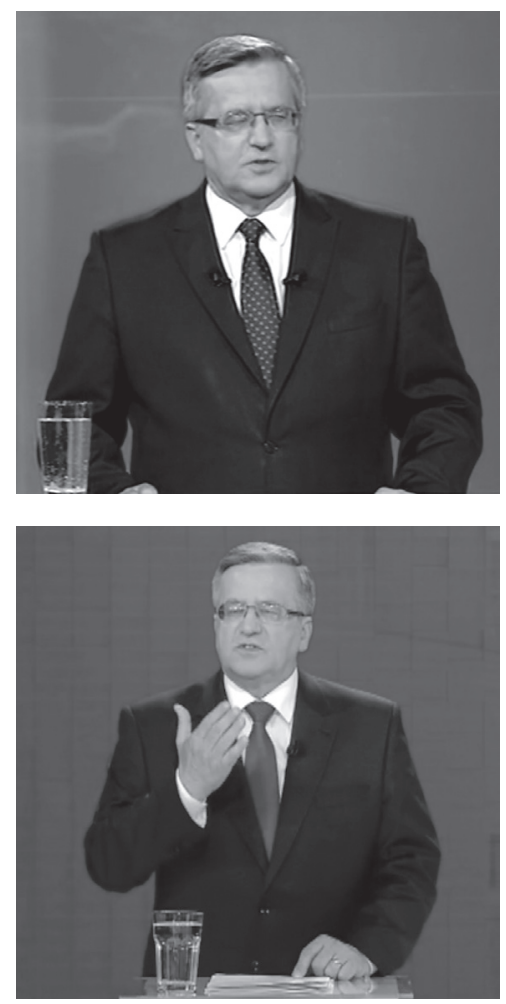

Picture 4. Komorowski's expression of doubt

Source: TVP Info. Retrieved on August 20, 2016, from http:// www.tvp.info/20097155/80-minut-starcia-na-wyborczym-ringuzobacz-cala-debate-komorowskiduda.
Picture 5. Komorowski's expression of disapproval and anger

Source: TVN 24. Retrieved August 20, 2016, from http://www. tvn24.pl/wiadomosci-z-kraju,3/stenogram-z-debaty-bronislawakomorowskiego-i-andrzeja-dudy,544561.html.

Duda's facial expressions were no less abundant. The presidential hopeful was blinking as nervously as Komorowski, and he often shut his eyes. He also used a practiced smile more often than a genuine one. However, comparing the faces of both candidates, Duda's eye movements were used to glance at his opponent or the debate chairman, and to create eye contact with the viewers. He once looked directly into the camera while speaking.

\section{Body posture and gestures}

Komorowski took a stable position standing firm on both legs, with shoulders lowered in a relaxed manner, and only sometimes were they lifted up. The symmetry of his figure was maintained in most situations, although he often swayed his entire body leftwards. Duda also took a stable position standing firm on both legs, with his shoulders lowered and the symmetry kept tight. He often lifted his chin up, which could indicate him feeling superior.

At the same time, hand gestures were used abundantly during the presidential appearances by both candidates. For example, Komorowski pointed at his opponent with his index finger (Picture 6) and used a gesture being a combination of the index finger and his thumb (Picture 7), which is a watered down version of pointing a finger at something/someone (Ekman, 2003). The de-escalation of a negative 

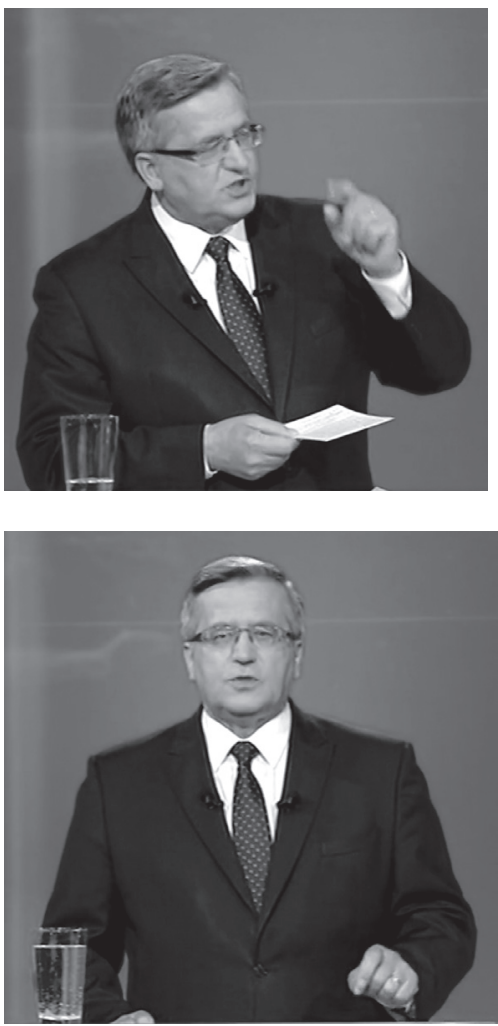

Picture 6. Komorowski pointing at his opponent

Source: TVN 24. Retrieved August 20, 2016, from http://www. tvn24.pl/wiadomosci-z-kraju,3/stenogram-z-debaty-bronislawakomorowskiego-i-andrzeja-dudy,544561.html.

Picture 7. A gesture combining the index finger and his thumb by Komorowski

Source: TVP Info. Retrieved August 20, 2016, from http:// www.tvp.info/20097155/80-minut-starcia-na-wyborczym-ringuzobacz-cala-debate-komorowskiduda.

gesture could diminish its supposed negative reception. Komorowski nervously counted on his fingers during some statements.

The examination of nonverbal communication revealed Komorowski's emotional engagement when he answered a pension-related question (slowing down, swallowing of prepositions, higher voice and nervous eyebrow raising), when he said that "some categories of people need to be protected" (face touching combined with higher pitch of voice).

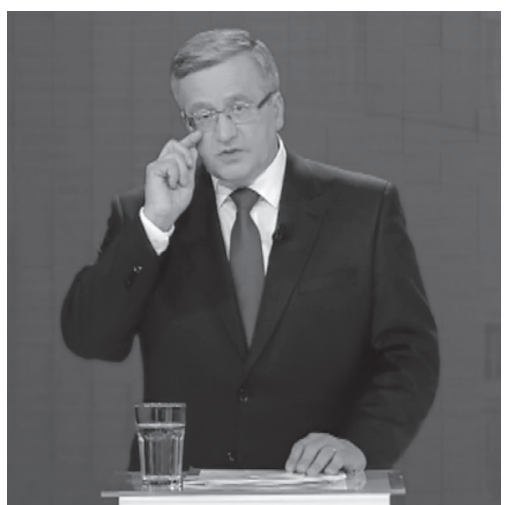

Picture 8. Komorowski's body language while talking about the public

Source: TVN 24. Retrieved August 20, 2016, from http://www. tvn24.pl/wiadomosci-z-kraju,3/stenogram-z-debaty-bronislawakomorowskiego-i-andrzeja-dudy,544561.html. 
At the same time, practiced gesturing of raising both arms used by Duda made him look fake and unnatural in contrast with the words spoken. He also used the combination of index finger and thumb (Picture 9) and counted on his fingers. During the pre-prepared statements he used the underscoring gesture, and some of the nervous gestures indicating indignation and anger (Picture 10). Moreover, Duda's high level of stress during both debates, manifested by self-calming gestures and fake smiles (engaging just his mouth but not his eye muscles) in many cases make it impossible to determine a consistency between verbal and nonverbal communication.

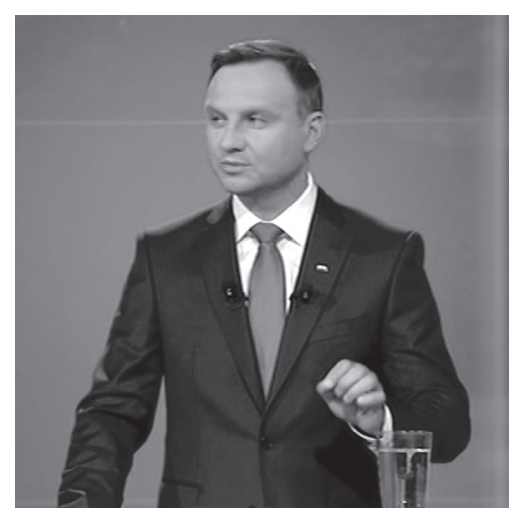

Picture 9. A combination of index finger and thumb by Duda

Source: TVP Info. Retrieved August 20, 2016, from http:// www.tvp.info/20097155/80-minut-starcia-na-wyborczym-ringuzobacz-cala-debate-komorowskiduda.

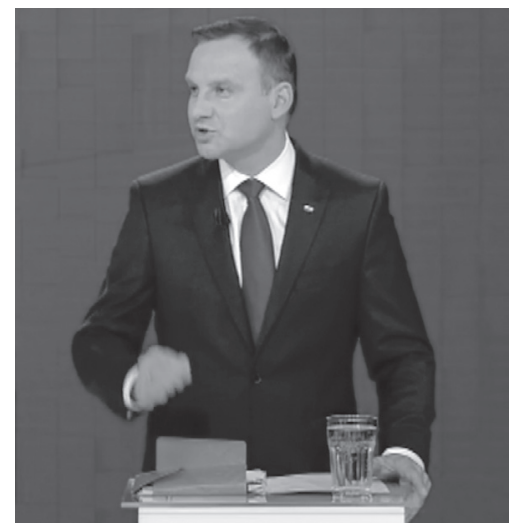

Picture 10. Gesture and face: anger expression by Duda

Source: TVN 24. Retrieved August 20, 2016, from http://www. tvn24.pl/wiadomosci-z-kraju,3/stenogram-z-debaty-bronislawakomorowskiego-i-andrzeja-dudy,544561.html.

\section{Touch}

The TVN debate began with an eight-second handshake (Picture 11), where the two opponents "fought" with strength and length of the handshake aiming at showcasing their superiority. It should be noted that it was Duda who approached the incumbent, emphasizing Komorowski's higher status. They maintained eye contact throughout the handshake. 


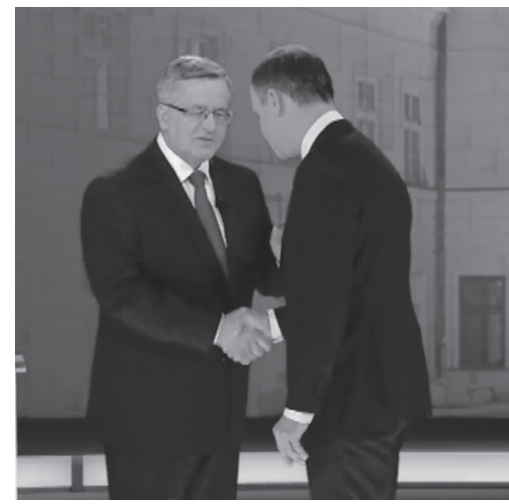

Picture 11. Handshake of opponents

Source: TVN 24. Retrieved August 20, 2016, from http://www. tvn24.pl/wiadomosci-z-kraju,3/stenogram-z-debaty-bronislawakomorowskiego-i-andrzeja-dudy,544561.html.

\section{Proxemics}

The television studio territory plays a significant role, as it is arranged in an intentional way to underline the importance of the situation or to make people within it seem smaller. Both the TVN and TVP studio are in blue: a color that manifests respect. The candidates' speaking platforms were placed far away from each other, marking their territory. The boundaries of these territories were breached both times. It seems that both candidates were aware that trespassing a territory may have a destructive effect on interpersonal communication (Leathers, 2007, p. 134). According to Altman and Sundstrom (1976, p. 54) people try to maintain optimal proximity in interactions, and violating it (whether by going closer or further away) provokes discomfort and dissatisfaction.

Duda entered Komorowski's territory to give him a flag with Civic Platform's colors (Picture 12) to underline the partisanship of the nonpartisan office. Komorowski returned the favor by handing Duda some documents to annunciate his lack of knowledge on certain topics. While Komorowski's gesture combined with crossing the distance and comfort zone boundaries revealed the candidate's need to manifest a sense of superiority, Duda's behavior may be interpreted as an accusation against the president of not representing all citizens, but just one political party.

With such nonverbal behavior Duda offered a distinction between the governing political party and its representative and the public. The message was strengthened by other nonverbal aspects mentioned in the section on appearance: a Polish flag pinned to his lapel and visible every time the camera presented him in a bust shot. 


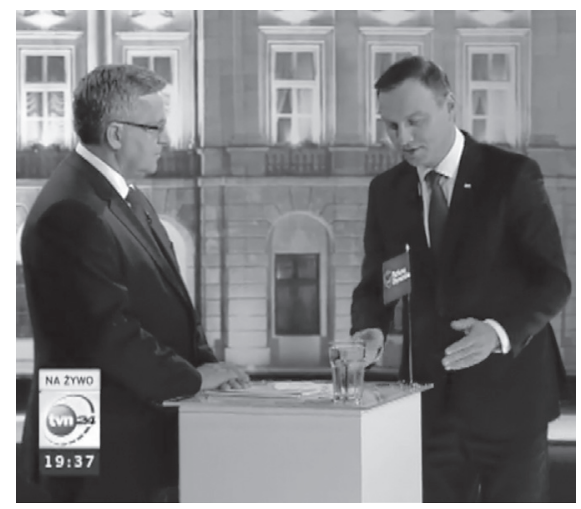

Picture 12. Trespassing of Komorowski’s territory by Duda

Source: TVN 24. Retrieved August 20, 2016, from http:// www.tvn24.pl/wiadomosci-z-kraju,3/stenogram-z-debatybronislawa-komorowskiego-i-andrzeja-dudy,544561.html.

\section{Nonverbal cues accompanying verbal messages on the public, elites, and others}

In order to trace nonverbal components of a populist style of communication, we conducted a nonverbal content analysis of the first debate (broadcast on May 17, 2015 on the public television channel - TVP1). The analysis of the verbal messages allowed us to recognize statements made by both candidates with clear and direct references to the main elements of populism: that is, the public, elites, or others. It is worth mentioning that most of the statements under study included references to the political elite. Such a finding supports previous observations on the prevalence of an anti-elitist type of populism (discrediting elites or blaming them) in Polish political actors' communication during the 2015 election campaign (Stępińska \& Adamczewska, 2017). Still, we were able to recognize several cases of references to the public (approaching the public, praising the public, or presenting the Polish population as a homogeneous group sharing the same values, goals, and characteristics). Less attention was paid during that debate to the issue of others.

Let us present the main observations on the nonverbal cues that accompanied verbal messages, including the critical evaluation of the political elite. Such statements were made by both presidential candidates while discussing the following issues suggested by journalists who hosted the debate: (1) Poland's security, NATO, and state of Poland's armed forces, (2) employment and economic migration, (3) and beneficiaries of 25 years of transformation in Poland.

First, in response to the question about the main pillars of Poland's security and the absence of NATO soldiers in Poland, Duda criticized the current government at that time, that is, a coalition of two political parties: Civic Platform and Polish People's Party, and Komorowski's performance (first as the Speaker of the Sejm, then as President). During Duda's statement about the political elite's lack of initiatives on ratification of the missile defense agreement, his face signaled strong surprise and a sense of helplessness. Komorowski used a similar verbal strategy of blaming the political elite (in that case, Law and Justice [in power 2005-2007]) for the lack of any success in regard to relations with NATO and bringing international soldiers to Poland. His critical 
statement was complemented by a nervous, accelerated and raised voice, and a triple use of his index finger. This gesture may be read as nonverbal manifestation, blaming and a sign of willingness to treat the opponent in a belittling manner (Navarro, 2008).

Furthermore, while responding to the question about the condition of Poland's armed forces Komorowski again criticized Law and Justice (twice) and combined his statement once again with a gesture of pointing his finger and a gesture of pushing away the space in front of him. Such behavior, accompanied with a facial expression indicating disgust, may be interpreted as a rejection of and detachment from the opponent (Ekman \& Friesen, 1978; Harrison, 2018).

Duda, while answering the same question, pointed out numerous inconsistencies in Komorowski's behavior during his entire political career and he blamed the political elite for the poor condition of Poland's armed forces. At that moment, Duda's face showed a particular contradiction: anger combined with a smile, suggesting a sense of superiority. His voice, on the other hand, changed into more dynamic, embedded, and self-confident. He complemented this behavior with the gesture of pointing with the index finger towards the floor that could indicate the desire to belittle his opponent (Ekman \& Friesen, 1978).

In the second part of the debate the issue of economic and social policy was raised. This time it was mostly Komorowski who took the opportunity to criticize Law and Justice's performance in 2005-2007 and blaming it for high rates of unemployment among young Poles that forced them to leave the country and look for work abroad. This statement was accompanied by such nonverbal behavior as: finger pointing, a raised voice, and the facial expression of disgust.

On the other hand, Duda used the strategy of blaming elites while discussing the issue of beneficiaries of 25 years of political and economic transformation in Poland. He verbally attacked Civic Platform, Komorowski, and Donald Tusk (a former prime minister). The body posture accompanying this statement indicated a self-confidence that was confirmed by controlled gestures and a calm, low, subdued voice.

At the same time, the presidential candidates varied in the way of making references to the public (both verbally and nonverbally) during the debate. Duda while responding to the problem of the "Polish-Polish war" raised by a journalist in the television studio - referred to the Polish nation as a whole and stressed that the president should serve everyone, regardless of differences within the nation. He said this with a softly hushed voice with some pleasant tones. However, when speaking of the openness to a discussion and views of various social groups, he changed his tone to a strong one. The strengthening tone of voice was accompanied by pointing his index finger towards Komorowski.

Answering the same question, Komorowski described Poles as those who need to agree with each other (he repeated this phrase twice), but with a surprised expression on his face, which could indicate surprise at his own words. The impression was emphasized by the slight movement of the left elbow and shoulder that may indicate he was not entirely truthful while speaking about it (Ekman, 2003). 
Furthermore, he referred to the achievements of the Polish people, presenting them as those who should be praised for building and developing their country. At the same time, he criticized Law and Justice for portraying Poland as a "country of ruin and burns." His nonverbal communication supported these statements with a raised, nervous voice and frequent eye contact with Duda, accompanied by pointing a finger at him while speaking about Law and Justice.

Two elements of populist style, that is, a reference to the public and a critical attitude towards elites, were also present in the part of the debate where candidates could ask each other questions. Both candidates took the opportunity to criticize his opponent and the political party he represented. During such statements, they produced a similar pointing gesture and showed a willingness to belittle their rival, since they directed their index finger right at the interlocutor or at the floor. Komorowski often used long-lasting eye contact, with a notable nervous and uncontrolled voice and breathing, which often revealed negative emotions of anger, impatience, and surprise, combined with fear (Ekman, 2003).

Duda, on the other hand, seemed to be less certain, more embarrassed, and reluctant to maintain long eye contact. He used more gestures than Komorowski, but they were not always consistent with the spoken words (the gestures appeared after the spoken word, not a moment before). However, he was able to control his voice and breathing.

It was Komorowski who made some reference to the public in that part of the debate, too. He expressed his concern by saying that people should be looked after, appreciated, and invited to engage in close cooperation. However, the movements of his shoulders again indicated the untruthfulness of his statement (Ekman, 2003).

\section{CONCLUSION AND FURTHER RESEARCH}

The aim of the study was to describe and compare nonverbal communication cues used by two main presidential candidates in Poland in 2015 during two television debates, as well as to recognize nonverbal components of a populist style of communication (appealing to emotions, notions of community, and creating bonds with the viewers, as well as expressing negative attitudes towards the political elite or others).

The study showed that both candidates employed nonverbal cues such as appearance, eye contact, facial expressions, or gestures that could emphasize their attitude towards the public or elites. We were able to recognize a few clear examples of nonverbal components of a populist style that supported a verbal reference to the public or manifested a negative attitude towards a rival (as a representative of the elites). Since most of the verbal statements expressed a critical attitude towards the political elite (including the rival in the presidential race), the spectrum of nonverbal cues expressing negative emotions (anger) and attitudes (distrust, criticism, or detachment) was the broadest, including facial expression, pointing fingers, a long handshake with eye contact manifesting competition, and trespassing the rival's territory in the television 
studio. While referring to the public, candidates used eye contact via a direct look to the camera. Duda also used a Polish flag as an element of his own appearance to emphasize his belongingness to the nation, and the flag of his rival's political party as a symbol of Komorowski's belongingness to the political elite.

However, our study also revealed that a high level of stress manifested by politicians, as well as professional training may significantly affect their behavior and hinder the examination of nonverbal communication. Based on numerous trained facial expressions (e.g., a trained smile) and gestures (e.g., pointing of fingers), we may conclude that both candidates tried to fulfill the audience's traditional expectation of a typical "presidential performance," presenting themselves nonverbally without unnecessary emotions and dramatic gestures. At the same time, each of them was able to control his level of stress to varying degrees, which could be recognized by the tone of voice and blinking. Hence, although the use of some cues of nonverbal communication of both candidates was similar (those that can be controlled to at least some extent), they differed in regards of the use of cues that are more difficult to control under stressful circumstances.

Moreover, a few general conclusions may be drawn from our study. First of all, the study showed that methods used previously in the research on nonverbal content of television content (namely, observational protocols and analysis of facial expressions: FACS) may be successfully employed in the studies on nonverbal components of the populist style of communication.

Secondly, against our expectations, the context of a presidential television debate led rather to unification than differentiation of nonverbal behavior of the candidates. It seems that the self-presentation of both candidates during the analyzed debates was a derivative of a highly formalized communication situation (setting, script, and topics were negotiated $a$ priori), which combined with professional training resulted in only a limited amount of spontaneous behavior. Nevertheless, such a planned performance may be perceived and studied as a nonverbal manifestation of populism, defined as a political style.

Therefore, in order to collect more material and conduct a profound analysis, further studies should take into consideration the following: (1) a wide variety of communication situations and contexts, (2) more political actors, and (3) other populist elements (besides just the references to the public, elites, and others) included in verbal messages that are accompanied by nonverbal communication, (4) more nonverbal cues (such as the ambiance, including a physical setting or venue, and persons accompanying the speaker, as well as the background selected for the speeches, and the prospect of recording/photo props used during the speeches).

\section{ACKNOWLEDGMENTS}

This work is funded by the National Science Centre, Poland, grant ID: 2015/18/M/ HS5/00080. 


\section{REFERENCES}

Albertazzi, D., \& McDonnell, D. (2008). Introduction: A new spectre for Western Europe. In D. Albertazzi \& D. McDonnell (Eds.), Twenty-first century populism: The spectre of Western European democracy (pp. 1-11). Basingstoke: Palgrave Macmillan.

Altmann, J., \& Sundstrom, E. (1974). Observational study of behavior. Chicago: University of Chicago Press.

Aronson, E., Wilson, T. D., \& Akert, R. M. (1997). Psychologia społeczna. Serce i umyst [Social psychology. Heart and mind] (A. Bezwińska et al., Trans.). Poznań: Wydawnictwo Zysk i S-ka.

Auer, J. J. (1962). The counterfeit debates. In S. Kraus (Ed.), The great debates: Background, perspective, effects (pp. 142-149). Bloomington: Indiana University Press.

Bierach, A. I. (2001). Mowa ciała kluczem do sukcesu [Body language as the key to success]. Wrocław: Wydawnictwo Astrum.

Borg, J. (2011). Język ciała [Body language] (M. Złoch, Trans.) Warszawa: Polskie Wydawnictwo Ekonomiczne.

Bracialle, R., \& Martella, A. (2017). Define the populist political communication style: The case of Italian political leaders on Twitter. Information, Communication \& Society, 20(9), 1310-1329.

Bucy, E. (2018). Presentation at the seminar on "Politics as Performance: Will the American fascination with 'Trump style' survive the 2018 midterms," London School of Economics, October 31, 2018. Retrieved December 10, 2018, from http://blogs.lse.ac.uk/government/2018/11/09/ politics-populism-and-performance-understanding-trump-style/.

CBOS. (2015). Odbiór kampanii wyborczej i aktywność polityczna w internecie przed wyborami parlamentarnymi [Reception of electoral campaign and political activity online before the parliamentary elections], no. 164.

Choi, Y. S., \& Benoit, W. L. (2013). A functional analysis of the 2007 and 2012 French presidential debates. Journal of Intercultural Communication Research, 42(3), 215-227.

de Vreese C. H., Esser F., Aalberg T., Reinemann C., \& Stanyer J. (2018). Populism as an expression of political communication content and style: A new perspective. The International Journal of Press/ Politics, 23(4), 423-438.

Ekman, P. (1982). Facial expression and facial nerve surgery. In M. D. Graham \& W. F. House (Eds.), Disorders of the facial nerve (pp. 363-368). New York: Raven Press.

Ekman, P. (2001). Facial expressions. In C. Blakemore \& S. Jennett (Eds.), The Oxford Companion to the Body (pp. 169-222). London: Oxford University Press.

Ekman, P. (2003). Kłamstwo i jego wykrywanie w biznesie, polityce i małżeństwie [Telling lies. Clues to deceit in the marketplace, politics, and marriage] (S. E. Draheim \& M. Kowalczyk, Trans.). Warszawa: PWN.

Ekman, P., \& Friesen, W. V. (1978). Facial Action Coding System: A technique for the measurement of facial movement. Palo Alto: Consulting Psychologists Press.

Fowler, S. (2018). Politics, populism, and performance: Understanding “Trump style". Retrieved December 10, 2018, from http://blogs.lse.ac.uk/government/2018/11/09/politics-populism-andperformance- understanding-trump-style/.

Friedman, H. S., DiMatteo, M. R., \& Mertz, T. I. (1980). Nonverbal communication on television news: The facial expressions of broadcasters during coverage of a presidential election campaign. Personality and Social Psychology Bulletin, 6(3), 427-435.

Gong, Z. H., \& Bucy, E. P. (2016). When style obscures substance: Visual attention to display appropriateness in the 2012 presidential debates. Communication Monographs, 83(3), 45-75.

Hameleers, M., Bos, L., \& de Vreese, C. (2017). They did it: The effects of emotionalized blame attribution in populist communication. Communication Research, 44(6), 870-900. 
Hamm, J., Kohler, C. G., Gur, R. C., \& Verma, R. (2011). Automated Facial Action Coding System for the dynamic analysis of facial expressions in neuropsychiatric disorders. Journal of Neuroscience Methods, 200(2), 237-256.

Harrison, S. (2018). The impulse to gesture: Where language, minds, and bodies intersect. Oxford: Oxford University Press.

Hart, R. P., \& Jarvis, S. E. (1997). Political debate: Forms, styles, and media. American Behavioral Scientist, 40(8), 1095-1122.

Hellweg, S. A., Pfau, M., \& Brydon, S. R. (1992). Televised presidential debates: Advocacy in contemporary America. New York: Praeger.

Jagers, J., \& Walgrave, S. (2007). Populism as political communication style: An empirical study of political parties' discourse in Belgium. European Journal of Political Research, 46(3), 319-345.

Jansen, R. S. (2011). Populist mobilization: A new theoretical approach to populism. Sociological Theory, 29(2), 75-96.

Keltner, D., Ekman, P., Gonzaga G. C., \& Beer, J. (2003). Facial expression of emotion. In R. J. Davidson, J. R. Scherer, \& H. H. Goldsmith (Eds.), Handbook of affective sciences (pp. 415-432). New York: Oxford University Press.

Kriesi, H. (2014). The populist challenge. West European Politics, 37(2), 361-378.

Laclau, E. (2005). On populist reason. New York: Verso Books.

Leathers, D. G. (2007). Komunikacja niewerbalna [Nonverbal communication] (M. Trzcińska, Trans.). Warszawa: PWN.

Łoszewski, K. (2014). Dress code. Tajemnice męskiej elegancji [Dress code. The secrets of male elegance]. Olszanica: BOSZ.

Margulies, B. (2017). Book review: The global rise of populism: Performance, political style and representation by Benjamin Moffitt. Retrieved December 10, 2018, from http://blogs.lse.ac.uk/lsereviewofbooks/2017/11/20/book-review-the-global-rise-of-populism-performance-political-style-and-representation-by-benjamin-moffitt/.

McKinney, M. S., \& Carlin, D. (2004). Political campaign debates. In L. L. Kaid (Ed.), Handbook of political communication research (pp. 203-244). Mahwah, NJ: Lawrence Erlbaum.

Moffitt, B. (2016). The global rise of populism: Performance, political style and representation. Redwood City: Stanford University Press.

Moffit, B., \& Tormey, S. (2014). Rethinking populism: Politics, mediatisation, and political style. Political Studies, 62(2), 381-397.

Mudde, C. (2004). The populist Zeitgeist. Government and Opposition, 39(4), 542-563.

Navarro, J. (2008). What everybody is saying. New York: Harper Collins.

Nimmo, D. (2001), Political persuaders: The techniques of modern election campaigns. New BrunswickLondon: Transaction Publishers.

Reinemann, C., Aalberg, T., Esser, F., Strömbäck, J., \& de Vreese, C. (2017). Populist political communication: Toward a model of its causes, forms, and effects. In T. Aalberg, F. Esser, C. Reinemann, J. Strömbäck, \& C. de Vreese (Eds.), Populist political communication in Europe (pp. 12-25). New York: Routledge.

Schrott, P. R. (1990). Electoral consequences of "winning" televised campaign debates. Public Opinion Quarterly, 54(4), 567-585.

Sikorski, W. (2011). Niewerbalna komunikacja interpersonalna [Nonverbal interpersonal communication]. Warszawa: Difin.

Stępińska, A., \& Adamczewska, K. (2017). Obecność stylu populistycznego w mediach informacyjnych podczas kampanii wyborczej w 2015 roku [Presence of a populist style in news media during the election campaign in 2015]. e-Politikon, 24, 59-86.

Wodak, R., \& Pelinka, A. (Eds.). (2002). The Haider phenomenon in Austria. New Brunswick: Transaction Publishers. 